\title{
PRODUCTION OF Bacillus thuringiensis BIOPESTICIDE USING COMMERCIAL LAB MEDIUM AND AGRICULTURAL BY-PRODUCTS AS NUTRIENT SOURCES.
}

\author{
FERNANDO HERCOS VALICENTE ${ }^{1}$, EDMAR DE SOUZA TUELHER ${ }^{1}$, MARIA \\ ISABELLA SANTOS LEITE ${ }^{2}$, FERNANDA LYON FREIRE ${ }^{2}$ and CORINA MACEDO \\ VIEIRA $^{2}$
}

${ }^{1}$ Embrapa Milho e Sorgo, C.P. 151, Rod. MG 424, Km 65, 35700-068, Sete Lagoas, MG, valicent@cnpms.embrapa.br

${ }^{2}$ Biological Science Students

Revista Brasileira de Milho e Sorgo, v.9, n.1, p. 1-11, 2010

\begin{abstract}
Bacillus thuringiensis $(B t)$ is a Gram-positive bacterium naturally found in soil, water and grain dust, and can be cultivated in liquid, solid and semi-solid media. The objective of this work was to test different media to grow B. thuringiensis. The seed culture (strain 344, B. thuringiensis tolworthi, belonging to Embrapa Maize and Sorghum Microorganism Bank) was produced using shake flasks and grown in LB medium plus salts during 18 hours, incubated on a rotary shaker at 200 revolutions per minute (rpm) at $30^{\circ} \mathrm{C}$ for 96 hours. Medium 1 was composed of: Luria Bertani (LB) plus salts $\left(\mathrm{FeSO}_{4}, \mathrm{ZnSO}_{4}, \mathrm{MnSO}_{4}, \mathrm{MgSO}_{4}\right)$, and $0.2 \%$ glucose; medium 2 was composed of $1.5 \%$ glucose, $0.5 \%$ soybean flour plus salts; and medium 3 was composed of liquid swine manure at $4 \%$ and $0.2 \%$ glucose. All three media were sterilized and inoculated with $B$. thuringiensis tolwothi (seed culture) at a stirrer speed of 200rpm, for 96 hours at $30^{\circ} \mathrm{C}$. The $\mathrm{pH}$ was measured at regular intervals, viable spores were counted as c.f.u $/ \mathrm{mL}$, cell mass expressed in $\mathrm{g} / \mathrm{L}$ - lyophilized, and spore counting per $\mathrm{mL}$ of medium. All three media showed $\mathrm{pH}$ variation during the fermentation process. Media 1 and 2 showed a tendency to shift toward a basic $\mathrm{pH}$ and medium 3 to an acidic $\mathrm{pH}$. Media 1 and 2 showed the highest number of viable spores, $2.0 \times 10^{8} \mathrm{c} . f . \mathrm{u} / \mathrm{mL}$, within the 96 hours of incubation, however medium 2 showed a biomass dry weight of $1.18 \mathrm{~g} / \mathrm{L}$. During the fermentation period, medium 1 showed the highest spore concentration, $1.4 \times 10^{9}$ spores $/ \mathrm{mL}$ after $96 \mathrm{~h}$ of fermentation. Efficiency against $S$. frugiperda first instar larvae showed that all $B t$ produced in all three media killed above $60 \%$ in the highest concentrations.
\end{abstract}

Key words: Spodoptera frugiperda, biocontrol, insect pest management, microbial insecticide. 


\section{PRODUÇÃO DE BIOPESTICIDA À BASE DE Bacillus thuringiensis USANDO MEIO COMERCIAL E SUBPRODUTOS DA AGRICULTURA COMO FONTES DE NUTRIENTES}

RESUMO - Bacillus thuringiensis (Bt) é uma bactéria Gram positiva encontrada naturalmente nos solos, água e resíduos de grãos e pode ser cultivada em meio líquido, sólido e semisólido. O objetivo deste trabalho foi testar diferentes meios para o crescimento do B. thuringiensis. O inóculo semente, constituído da cepa de Bt 344 (B. thuringiensis tolworth - pertencente ao Banco de Microorganismos da Embrapa Milho e Sorgo) foi crescido durante 18 horas e inoculado em três meios de cultura líquidos, que foram mantidos sob agitação constante (200rpm), por um período de 96 horas, a $30^{\circ} \mathrm{C}$. O meio 1 foi constituído pelo meio comercial Luria Bertani, enriquecido com sais $\left(\mathrm{FeSO}_{4}, \mathrm{ZnSO}_{4}\right.$, $\mathrm{MnSO}_{4}, \mathrm{MgSO}_{4}$ ) e glicose a $0,2 \%$; o meio 2, por glicose de milho a 1,5\%, farelo de soja a $0,5 \%$ e sais e o meio 3, por chorume a $4 \%$ (esterco líquido a base de fezes de suínos) e glicose a $0,2 \%$. Para cada um dos meios, mediu-se o $\mathrm{pH}$ a intervalos regulares, contouse esporos viáveis expressos em c.f.u/mL, pesou-se a massa celular e contou-se o total de esporos produzidos. Os três meios apresentaram variações ácido-básicas durante o período de fermentação, sendo os meios 1 e 2 com tendência ao $\mathrm{pH}$ básico e o meio $3 \mathrm{com}$ tendência ao $\mathrm{pH}$ ácido. Os meios 1 e 2 apresentaram maior número de esporos viáveis, com 2,0 x $10^{8}$ u.f.c. $/ \mathrm{mL}$, depois de 96 horas de crescimento. A maior massa celular total foi produzida pelo meio 2 , com média de $1,18 \mathrm{~g} / \mathrm{L}$. O meio 1 foi o que apresentou maior concentração de esporos totais, com $1,4 \times 10^{9}$ esporos $/ \mathrm{mL}$, após 96 horas de crescimento. A eficiência contra $S$. frugiperda de primeiro instar mostrou que todos os $B t$ produzidos nos três meios mataram acima de $60 \%$ nas maiores concentrações.

Palavras-chave: Spodoptera frugiperda, biocontrole, manejo de pragas, inseticida microbiano.

Bacillus thuringiensis $(B t)$ is the most successful commercial biopesticide in the biological control market (Yang \& Wang, 1998; Glare \& Callaghan, 2000) accounting for $90 \%$ of all biopesticides sold all over the world. $B$. thuringiensis is a Gram positive spore-forming bacterium found naturally in soil, water, dead insects and grain dust. This bacterium is characterized by its ability to produce crystalline inclusions proteins or crystals called endotoxin

Revista Brasileira de Milho e Sorgo, v.9, n.1, p. 1-11, 2010

Versão impressa ISSN 1676-689X / Versão on line ISSN 1980-6477 - http://www.abms.org.br 
during sporulation and/or stationary phase. The crystalline inclusions along with the spores have a great potential to control a great number of pest insects belonging to the order Lepidoptera, Diptera and Coleoptera (Vidyarthi et al., 2002). The $B t$ biopesticide preparations are based on endotoxin proteins accumulated as parasporal crystals produced by the bacterial cells. Various agricultural and industrial by-products may be used as raw materials in biopesticide industry, such as maize glucose, soybean flour, peanuts, sugarcane molasses, which also contain $\mathrm{N}$, and liquid swine manure. Morris et al. (1997) also mentioned less expensive complex sources of organic nitrogen such as grains, beans, oilseeds, fish and meat meals. Some carbohydrate sources also contain protein, and vice versa, and could serve as the sole source of nutrients for bacterial culture. Tirado-Montiel et al. (2001) first tested the use of wastewater sludge for the production of $B t$ based biopesticide, however, the entomotoxicity level reported in the paper was low. Moreover, the low cost of by-products as nutrient source in fermentation media of $B t$ biopesticide production has received little attention. However, a higher level of entomotoxicity is desired to reduce biopesticide production costs.

Fall armyworm, Spodoptera frugiperda, is one of the most important corn insect pests in Brazil and its damage may reduce yield production up to 34\% (Carvalho, 1970). The use of chemical insecticides to control $S$. frugiperda has increased over the years in Brazil, and has generated resistance of this insect to chemicals. Microbial pesticides may become feasible and reliable alternative to control this insect, however $B t$ based biopesticides is limited due to high production costs (Dulmage, 1981). B. thuringiensis strains have a narrow spectrum of insecticidal activity when compared to conventional chemicals. Regarding specificity $B t$ shows differences even within an order of insects (e.g. Lepidoptera) and dramatic differences in sensitivity are exhibited among species (Bravo et al. 1998). Differences in sensitivity were found among species, i.e. Spodoptera spp. are difficult to control with $B t$ based biopesticide (strain HD1), however Heliothis virescens and Plutella xylostella are not (Baum et al. 1999). Waquil et al. (1982) also found that Bt was not much efficient against $\mathrm{S}$. frugiperda, but these authors used only one available biopesticide at that time (strain HD1). Nevertheless, the efficiency of $B$. thuringiensis depends on finding the specific and efficient strain to a specific insect pest. Valicente \& Lana (2009) characterized strain 344, Bt sv tolworthi, very efficient against fall armyworm larvae, and this strain was very stable during the fermentation process.

The use of raw materials in the fermentation media to produce $B t$ based biopesticide may become a reliable and cheap way to integrate this insect pathogen into the fall armyworm pest management, but these materials may vary due to local availability, cost and in both physical and chemical composition, due to the type of the primary source. The objective of this 
work was to evaluate the use of industrial raw material and liquid swine manure as the primary carbon and nitrogen sources to produce $B t$ based biopesticide, using a highly efficient strain against fall armyworm.

\section{Materials and Methods}

Bacterial strain: Bacillus thuringiensis sv tolworthi, strain 344, belonging to Embrapa Maize and Sorghum Microbial Bank was isolated from a soil sample. The sample was mixed with salt solution $(0.8 \%)$ and the flask was incubated on a rotary shaker for 18 hours. One milliliter of this suspension was heated in water bath at $80^{\circ} \mathrm{C}$ for 30 minutes, cooled in ice for 15 minutes and plated on sporulating medium composed of Luria Bertani (LB) enriched with salts (g. $\mathrm{L}^{-1}$ in distilled water) $0.002 \mathrm{~g} \mathrm{FeSO}_{4}, 0.02 \mathrm{~g} \mathrm{ZnSO}_{4}$, $0.02 \mathrm{~g} \mathrm{MnSO}_{4}, 0.3 \mathrm{~g} \mathrm{MgSO}_{4}$ and $2 \mathrm{~g}$ glucose. The $\mathrm{pH}$ was adjusted to 7.2. After 24-72 incubating at $30 \pm 1^{\circ} \mathrm{C}$, colonies were observed on a phase contrast microscope.

Media preparation: Strain 344 was sub cultured in medium composed of Luria Bertani (LB) enriched with salts (g.L $\mathrm{L}^{-1}$ in distilled water) $0.002 \mathrm{~g} \mathrm{FeSO}_{4}, 0.02 \mathrm{~g} \mathrm{ZnSO}_{4}, 0.02 \mathrm{~g} \mathrm{MnSO}_{4}, 0.3 \mathrm{~g}$ $\mathrm{MgSO}_{4}$ and $2 \mathrm{~g}$ glucose and $\mathrm{pH}$ adjusted to 7.5. After sub culturing, strain 344 was streaked on sporulating medium containing the same salts plus $12 \mathrm{~g}$ of Bacto-Agar (Difco), 8.0g of nutrient broth, and incubated for 24 hour at $30 \pm 1^{\circ} \mathrm{C}$ and maintained at $4^{\circ} \mathrm{C}$ for future use.
Medium 1 was composed of lab commercial Luria Bertani (LB) plus salts $\left(\mathrm{FeSO}_{4}\right.$, $\mathrm{ZnSO}_{4}, \mathrm{MnSO}_{4}, \mathrm{MgSO}_{4}$ ), and $0.2 \%$ glucose; medium 2 was composed of $1.5 \%$ glucose, $0.5 \%$ soybean flour plus salts; and medium 3 was composed of liquid swine manure (LSM) at 4\%. Liquid swine manure (LSM) was collect 32 days after fermentation, under field conditions when the $\mathrm{C}: \mathrm{N}$ ratio is considered to be stable. LSM was diluted to $4 \%$ and enriched with $1.5 \%$ soybean flour and $0.5 \%$ glucose. All three media were sterilized at $121^{\circ} \mathrm{C}$ for 30 minutes.

Seed culture preparation: A loopful of strain 344 from Bacto-Agar plates was used to inoculate a $500 \mathrm{~mL}$ Erlenmeyer flask containing $150 \mathrm{~mL}$ of sterilized LB medium enriched with salts. The flasks were incubated on a rotary shaker at $250 \mathrm{rpm}$ at $30^{\circ} \mathrm{C}$ for $12-16$ hours. The actively growing cells from these flasks were used as a second inoculum for the production in Erlenmeyer flasks.

Growth of $B$. thuringiensis tolworthi in three different media: The $500 \mathrm{~mL}$ Erlenmeyer flasks containing $150 \mathrm{~mL}$ of sterilized media 1, 2 and 3 were inoculated with strain 344 grown in the seed culture. A $5 \%(\mathrm{v} / \mathrm{v})$ inoculum from this flask was used to inoculate $500 \mathrm{~mL}$ Erlenmeyer flasks containing $150 \mathrm{~mL}$ of sterilized media. The flasks were incubated for 96 hours at $30^{\circ} \mathrm{C}$. Samples were withdrawn at different intervals and analyzed for colony forming units (CFU) of $\mathrm{VC}$ (viable cell) and heat resistant cells - viable 
spores (VS) by the serial plate technique on plates. The appropriately diluted samples were plated on agar plates and incubated overnight at $30^{\circ} \mathrm{C}$ to form fully developed colonies. Two replicates were used for each parameter. Each replicate of spore count, $\mathrm{pH}$ and heat resistant spores were checked three times.

Cell mass: Samples of $100 \mathrm{~mL}$ were centrifuged at $10000 \mathrm{rpm}$ for 20 minutes. The supernatant was discarded and the pellet was lyophilized. Dry weight was calculated and expressed in gram per liter. The same sample was used for the spore count and toxicity test. Two replicates were used each one measured three times.

Spore count: For spore count culture samples were heat treated at $80^{\circ} \mathrm{C}$ for 15 minutes, serially diluted and plated on LB plus salts and glucose agar plates. Plates were incubated at $25 \pm 1^{\circ} \mathrm{C}$ for 24 hours to form fully developed colonies that were counted and expressed in colony forming units per $\mathrm{mL}$ (c.f.u./mL). Two replicates were used each one measured three times.

pH: The $\mathrm{pH}$ of all media was adjusted to 7.2 with $\mathrm{NaOH}$ after sterilization, and was measured at regular intervals during 96 hours of fermentation process. Two replicates were used each one measured three times.

Toxicity test: The spore crystal complex produced in different media was assayed against 2 day old larvae (first instar) laboratory-reared
S. frugiperda. First instar larvae were raised on an artificial diet for 2 days prior to the bioassay. The bioassays were conducted using corn leaf surface method, where strain 344 produced in three different media were prepared in sterile distilled water, and $18 \mu \mathrm{L}$ of each suspension on the corn leaf surface were provided to each larvae. Corn leaves were washed once with $0.5 \%$ sodium hypochlorite and two times with distilled water. Each bioassay included 7 doses of 2 replicates each, along with the appropriate control. Larval mortality was scored up to 4 days after larvae infection to check pathogenicity.

\section{Results and Discussion}

All three media showed an amount of carbon, nitrogen and mineral salts, including $\mathrm{Ca}$, $\mathrm{Mg}, \mathrm{Zn}, \mathrm{Fe}, \mathrm{Cu}, \mathrm{Mn}$ and $\mathrm{Na}$. (Table 1) enough to grow $B t$ during the fermentation process.

Results showed that the $\mathrm{pH}$ varied among the 3 media during 96 hours of fermentation, and since there was no $\mathrm{pH}$ control during the experiments, a $\mathrm{pH}$ fluctuation was observed (Figure 1). The commercial LB medium (1), rapidly increased $\mathrm{pH}$ in the first 5 hours of fermentation and quickly decreased the $\mathrm{pH}$ to 6.44 in the first 12 hours of fermentation. However, after this period it was the only medium that maintained the $\mathrm{pH}$ above 8 (Figure 1). Media 2 and 3 slowly decreased the $\mathrm{pH}$ in the first 24 hours, and reaching a minimum $\mathrm{pH}$ value around 4 within 48 hours of fermentation. Media 2 and 3 (glucose + soybean flour and LSM 


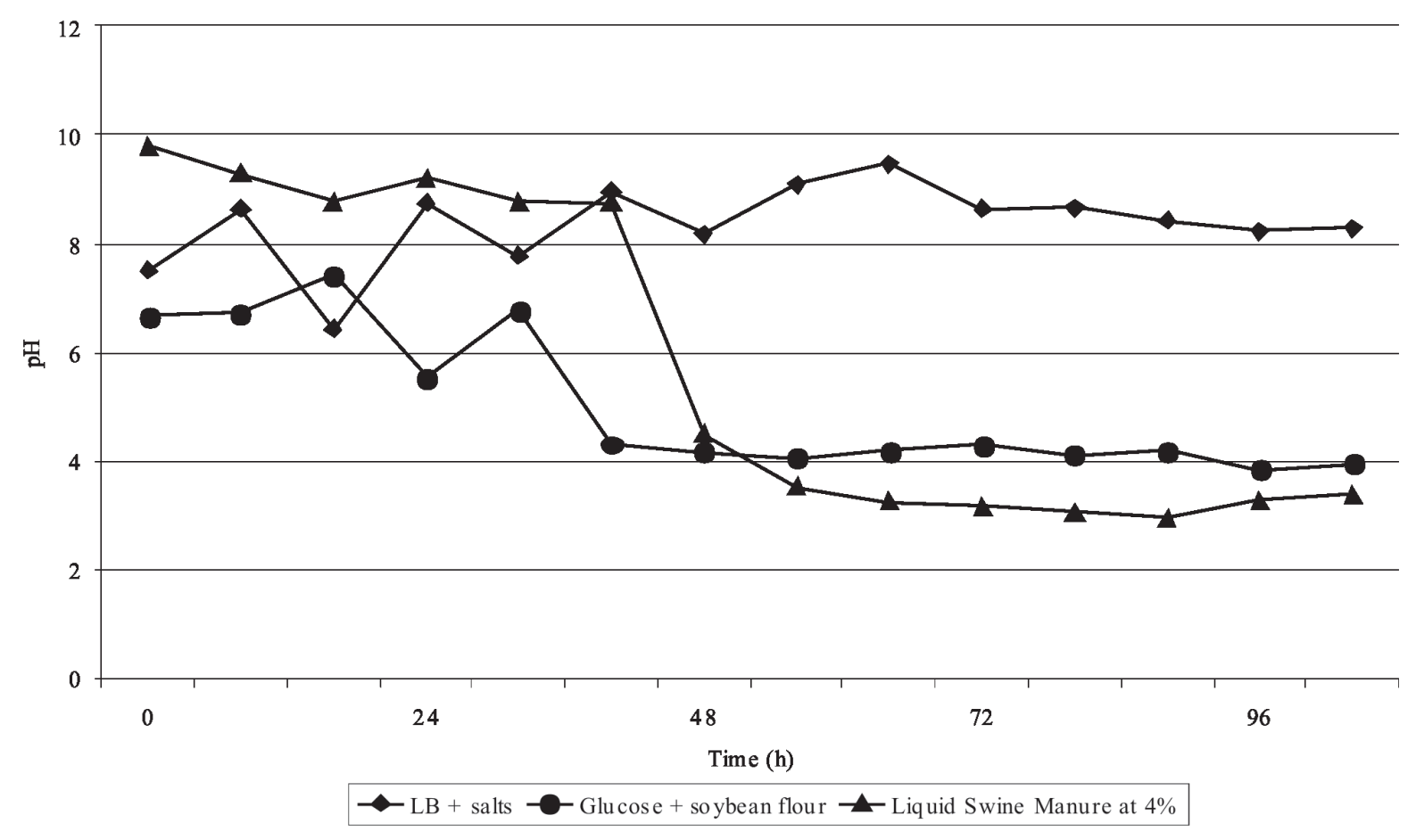

FIGURE 1. The $\mathrm{pH}$ variation at different intervals during the fermentation process of $B$. thuringiensis sv tolworthi in three media.

at $4 \%$, respectively) maintained a very low $\mathrm{pH}$ (between 3.86 and 2.97 minimum and 4.3 and 3.52 maximum) after 48 hours until the end of fermentation process (Figure 1). Tirado-Montiel et al. (2001) stated that this fact is probably due to the utilization of the carbohydrates before the sporulation phase was reached. These patterns of variation before $\mathrm{pH}$ stabilization were similar to those found by Tirado-Montiel et al. (2001); however they found that the final $\mathrm{pH}$ in the sludge samples stabilized between 8 and 8.5. Our data show that medium 2 (maize glucose + soy flour + salts) stabilized between 4.0 and 4.2 and media 3 (LSM at 4\%) stabilized between 3.3 and 3.4 (Figure 1). In a second $\mathrm{pH}$ replicate, all three media behaved like the first replicate; however, LSM at 4\% final $\mathrm{pH}$ stabilized between 6.03 and 6.51 (data not shown). Dingman \& Stahly (1983) stated that the decrease in $\mathrm{pH}$ is due to acid accumulation that results from catabolism of glucose, and this bioassay was added to the media 2 and 3.

Ejiofor \& Okafor (1989) and AbdelHameed et al. (1991) concluded that low pH 
could inhibit growth, sporulation and crystal formation of Bt, and Abdel-Hameed et al. (1991) also stated that if the $\mathrm{pH}$ of a culture medium is not between the range 6.5-7.5, sporulation and $\delta$-endotoxin formation could be adversely affected. This apparently occurred in medium 3 , LSM at 4\%, where the decrease in the $\mathrm{pH}$ during the fermentation possibly affected spore and crystal formation (Figure 2). Medium 2 continued to produce spores although $\mathrm{pH}$ was decreasing during the 96 hours of fermentation
(Figure 2); however medium 2 had a higher amount of glucose. The yield of spores in medium $1(\mathrm{LB}+$ salts + glucose $)$ was of the order of $1.4 \times 10^{9}$ spores $/ \mathrm{mL}$, and viable spores after 72 hours of fermentation was $2.0 \times 10^{8}$ c.f.u./ $\mathrm{mL}$. The yield of spores in medium 2 (maize glucose + soy flour) was of the order of $5.5 \mathrm{x}$ $10^{8}$ spores $/ \mathrm{mL}\left(2.0 \times 10^{8}\right.$ c.f.u. $/ \mathrm{mL}$ after 72 hours of fermentation) and medium 3 (LSM at 4\%) yielded spores in the order of $2.6 \times 10^{8}$ spores/ $\mathrm{mL}\left(1.5 \times 10^{8}\right.$ c.f.u. $\left./ \mathrm{mL}\right)($ Table 1$)$. In all three

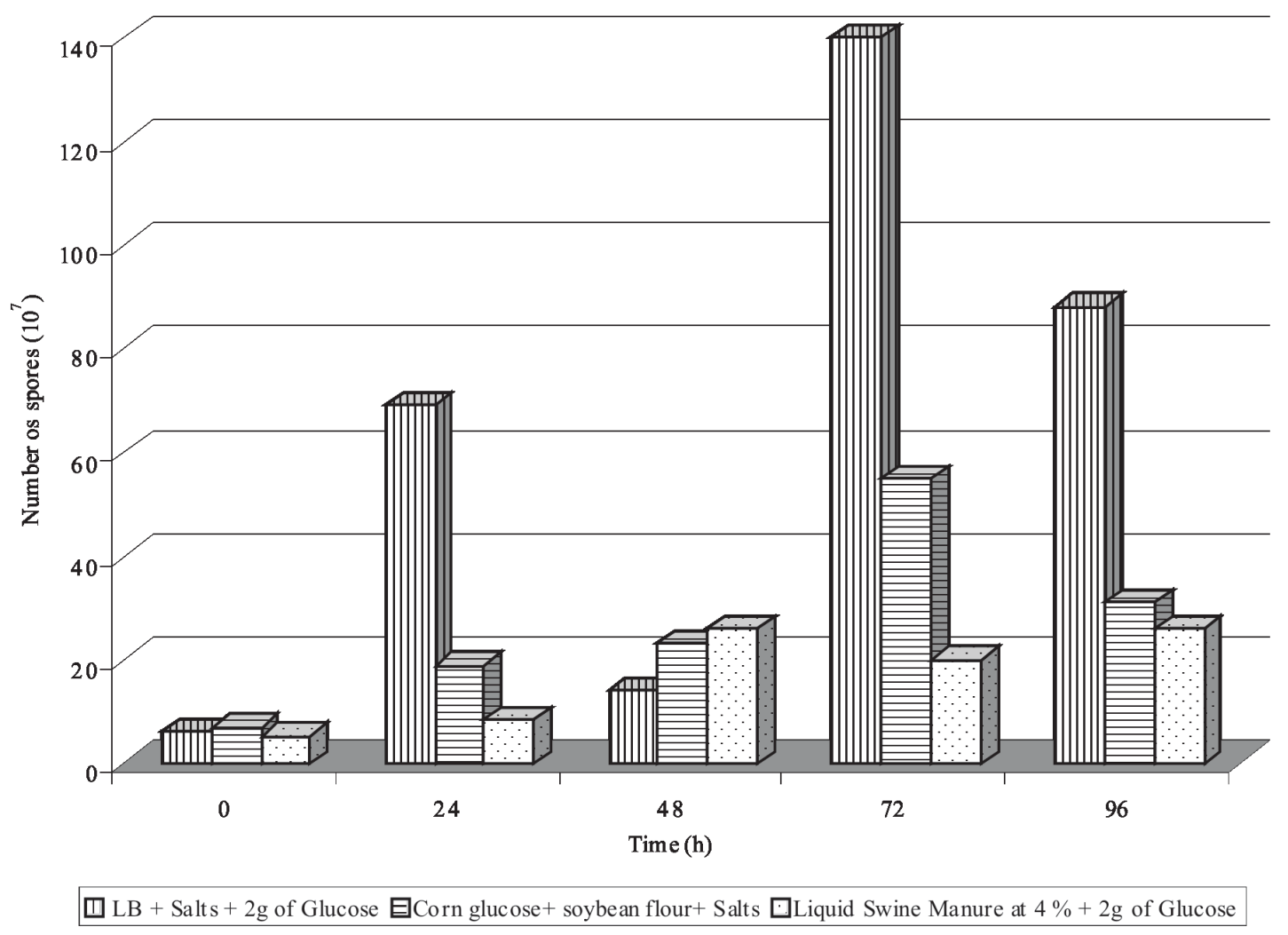

FIGURE 2. Number of spores of $B$. thuringiensis sv tolworthi produced in three media, harvested at different intervals during the fermentation process. 
TABLE 1. Analytical analysis of the three media used to grow Bacillus thuringiensis $\left(\mathrm{mgL}^{-1}\right)$.

\begin{tabular}{lccccccccccc}
\hline Media & $\mathbf{N}$ & $\mathbf{C}$ & $\mathbf{K}$ & $\mathbf{C a}$ & $\mathbf{M g}$ & $\mathbf{S}$ & $\mathbf{Z n}$ & $\mathbf{F e}$ & $\mathbf{C u}$ & $\mathbf{M n}$ & $\mathbf{N a}$ \\
\hline LB + salts & $18.883,2$ & $23.803,80$ & 770.0 & 2.92 & 32.08 & 99.18 & 7.23 & 6.30 & 0.23 & 9.33 & 163.3 \\
$\begin{array}{l}1.5 \% \text { glucose, 0.5\% } \\
\text { soybean flour plus salts }\end{array}$ & 544.71 & $12.971,83$ & 72.33 & 7.29 & 30.62 & 63.17 & 5.83 & 4.90 & 0.23 & 7.47 & 25.7 \\
$\begin{array}{l}\text { Liquid Swine manure } \\
(4 \%)\end{array}$ & 5426.9 & 4170.69 & 46.67 & 10.21 & 2.92 & 0.0 & 1.17 & 3.03 & 0.47 & 0.70 & 16.4 \\
\hline
\end{tabular}

media, the highest number of viable spores was reached after 96 hours of growth. According to Tirado-Montiel et al. (2001), the availability of carbon source can influence the yield of viable cells, spores and toxins in the $B t$ production process.

Cumulative cell mass of medium 2 (corn glucose + soy flour) reached its peak producing $1.18 \mathrm{~g} / \mathrm{L}$ and medium 3 (LSM at 4\%) produced the lowest amount of cell mass of $0.32 \mathrm{~g} / \mathrm{L}$ (Figure 3). Other results showed the same pattern where LSM produced the lowest dry weight (data not published). Apparently, a decrease in cell mass production occurred during the same period that the $\mathrm{pH}$ decreased in media 2 and 3 (Figure 3). It is also important to notice that the number of spores also decreased after 48 hours of fermentation for medium 3 (Figure 2).

The composition of the LSM at $4 \%$ is presented in Table 1. Usually LSM is a very good source of carbon, nitrogen, phosphorus, potassium and solids, and the concentration of these elements may vary according to their origin. LSM also contain toxic metals $(\mathrm{Cu}$,
$\mathrm{Zn}$ and $\mathrm{Mn}$ ) but their concentration was at an acceptable level according to Tirado-Montiel (2001). All these nutrients are important and may support growth, sporulation and endotoxin production by $B$. thuringiensis sv tolworthi. The presence of some toxic elements apparently did not affect the final viable cells and spore counts of $B t$, and the largest number of c.f.u occurred after 96 hours of fermentation (Table 1). Although media 2 and 3 produced fewer spores than the medium 1, these two media produced about the same amount of viable spores after 96 hours of fermentation (Table 1).

Mortality rates to all treatments combinations are in Figure 4. Two-way analysis of variance showed that larval mortality rate was influenced by media and spore concentration (Concentration: $\mathrm{F}=43.17, d f=9, p<0.001$; Medium: $\mathrm{F}=14.29, d f=9, p=0.002$ ) but not for its interaction (Concentration x Medium: $\mathrm{F}$ $=1.29, d f=9, p=0.34)$. Larval mortality was above $70 \%$ in the highest concentration for all three media and decreased as the concentrations decreased (Figure 4). This was probably 


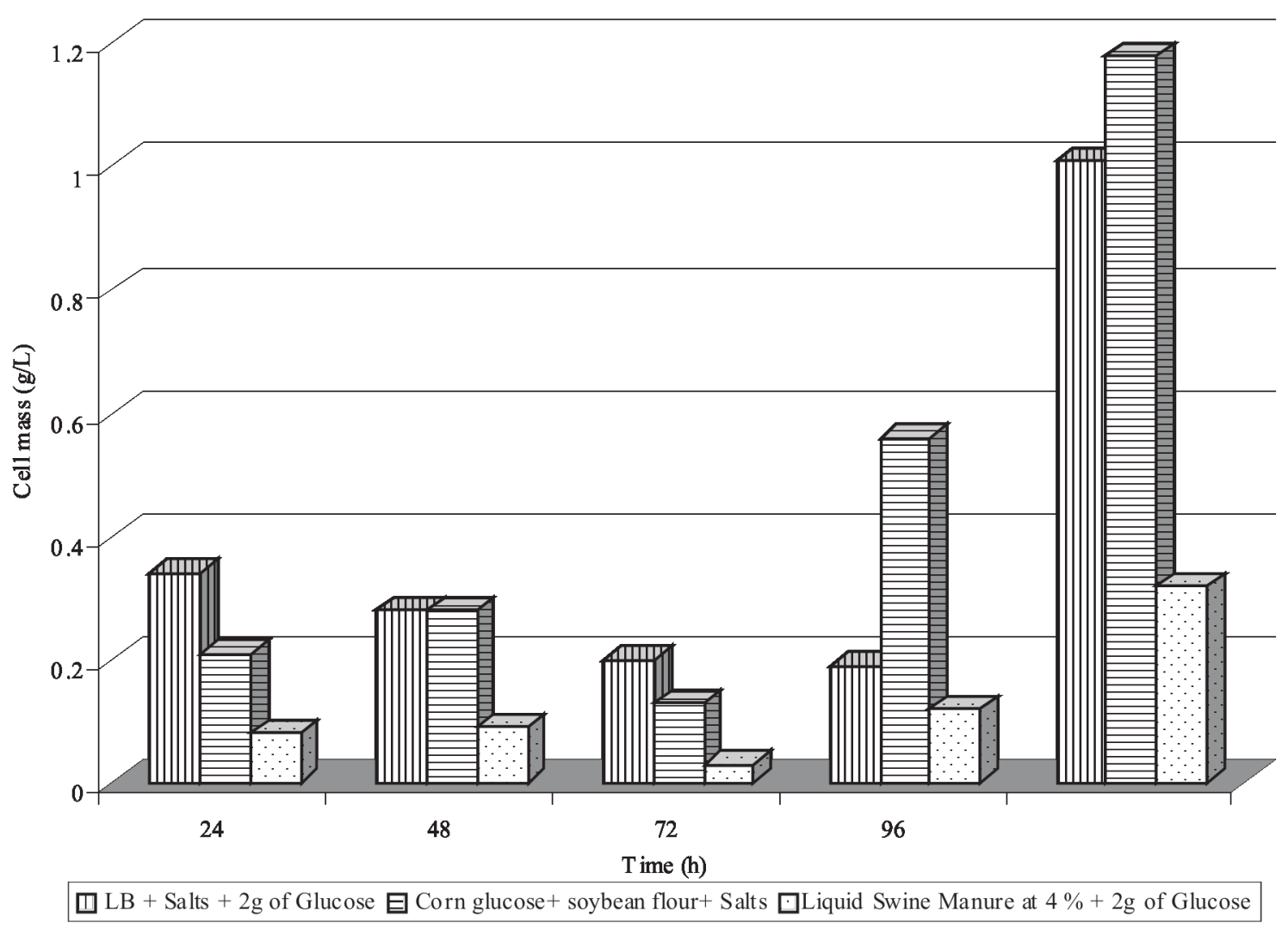

FIGURE 3. Freeze dried powder weight (dry biomass g/L) of B. thuringiensis sv tolworthi produced in three media during the fermentation process.

because the bioassays were conducted after $96 \mathrm{~h}$ of fermentation; however the highest number of spores occurred at $72 \mathrm{~h}$ of fermentation. Medium 1 showed higher larval mortality than other media, but no difference was detected between media 2 and 3. Although mortality caused by media 2 and 3 was 71 and $75.5 \%$, respectively at the highest concentrations, it is an important result, suggesting that these media can be efficient to produce $B t$ based biopesticides.
It is important to note that raw materials used for the production of $B t$ based microbial pesticides represent a substantial part of the overall production cost. Therefore it is important to find less expensive by-product sources than those currently used. The use of maize glucose, soybean flour and liquid swine manure represents a new alternative for disposal and/or recycling these substrates and minimize the $B t$ production costs. 


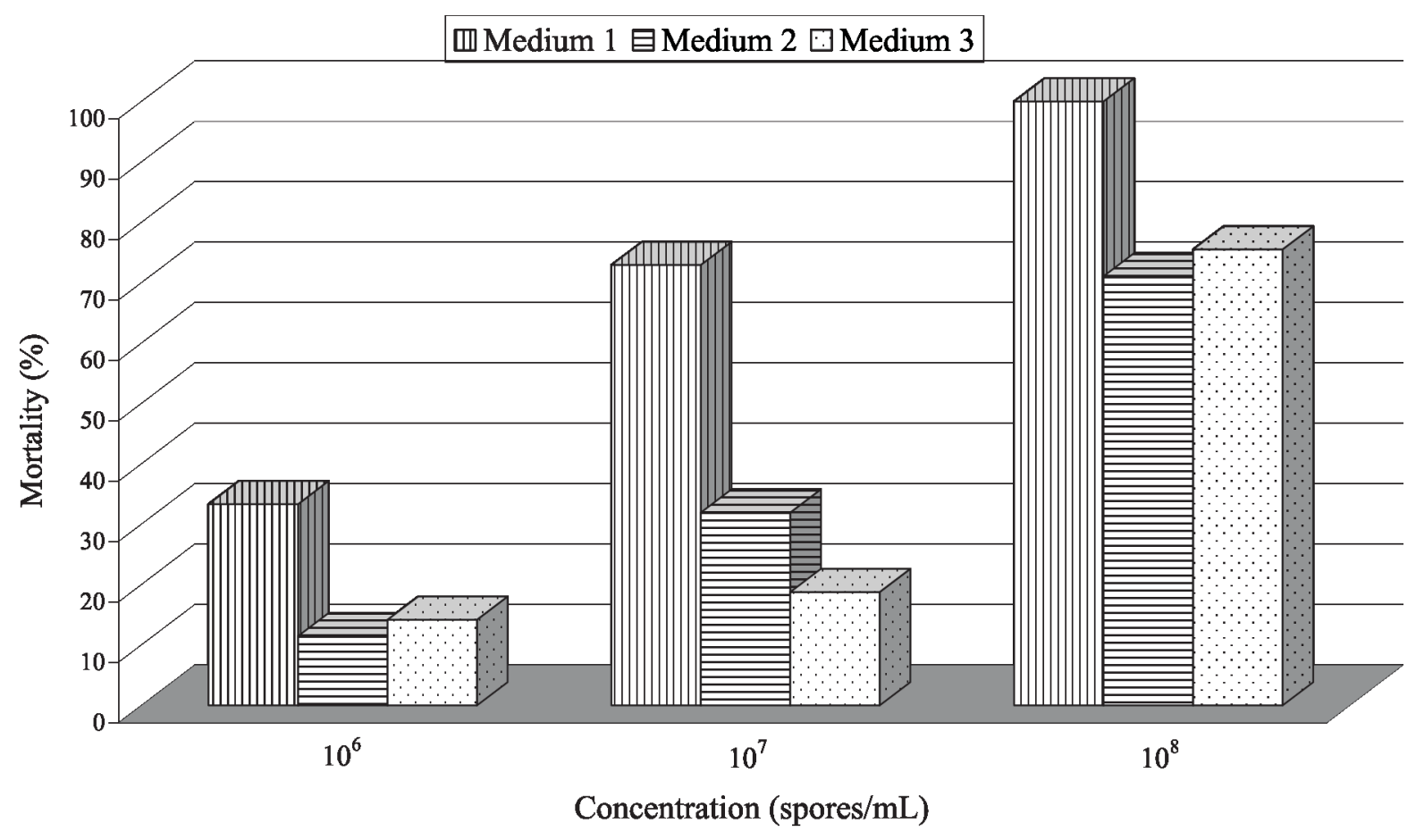

FIGURE 4. Mortality of first instar (two day old) Spodoptera frugiperda larvae with $B$. thurinngiensis sv tolworthi produced in three different media and concentrations.

\section{Acknowledgment}

The authors thank FAPEMIG (Fundação de Amparo à Pesquisa do Estado de Minas Gerais) for the financial support of this project.

\section{References}

ABDEL-HAMEED, A.; CARLBERG, G.; EL-TAYEB. O. M. Studies on the Bacillus thuringiensis $\mathrm{H}-14$ strains isolated in EgyptIV Characterization of fermentation conditions for $\delta$ endotoxin prodtucion. World Journal of
Microbiology and Biotechnology, Oxford, v. 7, p. 231-236, 1991.

BAUM, A. B.; JOHNSON, T. B.; CARLTON, B. C. Bacillus thuringiensis - Natural and recombinant biopesticide products. In: HALL, F. R.; MENN, J. J. (Ed.). Biopesticides: use and delivery. Totowa: Humana Press, 1999. p. 189209. (Methods in Biotechnology, 5)

BRAVO, A.; SARABIA, S.; LOPEZ, L.; ONTIVIEROS, H.; ABARCA, C.; ORTIZ, A.; LINA, L.; VILLALOBOS, F. J.; PEÑA, G.; NUÑES-VALDEZ，M. E.; SOBERÓN，M.; 
QUINTERO, R. Characterization of cry genes in a Mexican Bacillus thuringiensis strain collection. Applied and Environonmental Microbiology, Washington, v. 64, p. 4965-4972, 1998.

CARVALHO, R. P. L. Danos, flutuação da população, controle e comportamento de Spodoptera frugiperda (J.E.Smith, 1797) e susceptiblidade de diferentes genótipos de milho, em condições de campo. 1970. 170 f. Tese (Doutorado) - Escola Superior de Agricultura Luiz de Queiroz, Universidade de São Paulo, Piracicaba.

DINGMAN, D. W.; STAHLY, D. P. Medium promoting sporulation of Bacillus larvae and metabolism of medium components. Applied and Environmental Microbiology, Washington, v. 46, p. 860-869, 1983.

DULMAGE, H. T. Production of microbial insecticides by fermentation. In: BURGES, $\mathrm{H}$. D. (Ed.). Microbial control of pests and plant diseases. London: Academic Press, 1981. p. 143-222.

EJIOFOR, A. O.; OKAFOR, N. Production of mosquito larvicidal Bacillus thuringiensis serotype $\mathrm{H}-14$ on raw material media from Nigeria. Journal of Applied Bacteriology, Oxford, v. 67, p. 5-9, 1989.

GLARE, T. R.; O'CALLAGHAN, M. Bacillus thuringiensis: biology, ecology and safety. Chichester: J. Wiley. 2000. 350 p.

MORRIS, O. N.; KANAGARATNAM, P.; CONVERSE, V. Suitability of 30 agricultural products and by-products as nutrient sources for laboratory production of Bacillus thuringiensis subsp. aizawai (HD133). Journal of Invertebrate Pathology, San Diego, v. 70, p. 113-120, 1997.

TIRADO-MONTIEL， M. I.; TYAGI， R. D.; VALERO, J. R. Wastewater treatment sludge as a raw material for the production of Bacillus thuringiensis based biopesticides. Water Research, New York, v. 35, p. $3807-$ 3816, 2001.

VALICENTE, F. H.; LANA, U. G. P. Characterization of the Bacillus thuringiensis strains (Berliner) 344 and 1644, efficient against fall armyworm, Spodoptera frugiperda (J. E. SMITH). Revista Brasileira de Milho e Sorgo, Sete Lagoas, v. 7, p. 195-208, 2009.

VIDYARTHI, A. S.; TYAGI, R. D.; VALERO, J. R.; SURAMPALLI, R. Y. Studies on the production of $B$. thuringiensis based biopesticides using wastewater sludge as a raw material. Water Research, New York, v. 36, p. 4850-4860, 2002.

WAQUIL, J. M. ; VIANA, P. A. ; LUCENA, A. I. T.; CRUZ, I.; OLIVEIRA, A. C. . Controle da lagarta-do-cartucho em milho com inseticidas químicos e biológicos. Pesquisa Agropecuária Brasileira, Brasilia, DF, v. 17, n. 2, p. 163-166, 1982.

YANG, X-M.; WANG, S. S. Development of Bacillus thuringiensis fermentation and process control from a practical perspective. Biotechnology and Applied Biochemistry, Orlando, v. 28, p. 95-98, 1998. 
